u Zagrebu

abatinic@hazu.hr

\title{
Polonistička veza Julija Benešića i Zdenke Marković
}

Abstract: Batinić Ana, Polonistička veza Julija Benešića i Zdenke Marković (Polish-Studies Relationship Between Julije Benešić and Zdenka Marković). "Poznańskie Studia Slawistyczne" 9. Poznań 2015. Publishing House of the Poznan Society for the Advancement of the Arts and Sciences, pp. 467-492. ISSN 2084-3011.

Being a private form of communication, personal letters are usually not written to be published. The act of their publication, therefore, may be considered as somewhat voyeuristic. However, since the authors of the correspondence in this contribution - Julije Benešić and Zdenka Marković - are two public figures of great importance not only in Croatian literary and cultural context, but also in the promotion of Croatian Polish studies as well as intercultural relations between Croatia and Poland in the first half of the twentieth century, we believe that its printing is justified. Their correspondence may be considered as an interesting addition to the facts about their lives and work that can be found in different research papers and books published so far, providing insight in the inner world of thoughts and emotions they shared.

Keywords: Julije Benešić; Zdenka Marković; correspondence; Polish studies; intercultural relations; friendship

Najvažnija je značajka pisma njegova dijaloška priroda. Svaka korespondencija pruža svojevrstan uvid u misli, osjećaje, želje i svjetonazore pošiljatelja - ali i primatelja. Dvostrukost uvida proizlazi ne samo iz činjenice da se pismo upućuje drugome, nego i iz spoznaje da oni koji pišu, pišući o sebi, obično izravno ili neizravno otkrivaju i mnogo toga o osobi kojoj se obraćaju. Osobna pisma kao privatan oblik komunikacije gotovo nikada nisu pisana s namjerom da jednoga dana budu izložena oku javnosti pa bi se čak i njihovo čitanje, a posebice objavljivanje, moglo smatrati voajerizmom. Ovdje je, međutim, riječ o korespondenciji dviju fascinantnih javnih osoba hrvatske književne i kulturne povijesti, ali i slavističkog svijeta, koja nudi ponešto drugačiji pogled na njihove osobnosti - ,pogled iznutra” - zbog čega je njezino objavljivanje, vje- 
rujem, opravdano ${ }^{1}$. Obuhvatiti nečiji život u nekoliko rečenica uvijek je nezahvalna zadaća. To nezahvalnija što je život bio ispunjeniji. Sažeti životno djelo(vanje) Julija Benešića (Ilok, 1. ožujak 1883. - Zagreb, 19. prosinac 1957.) i Zdenke Marković (Požega, 10. siječanj 1884. - Zagreb, 14. studeni 1974.), istinskih zaljubljenika u poljsku kulturu te neumornih promicatelja međukulturnih, prijateljskih odnosa između Hrvatske i Poljske, u nekoliko suhoparnih, informativnih rečenica čini se, stoga, ne samo nemoguće, nego i nepravedno. Ipak, neke činjenice treba spomenuti, a epistolarni „razgovori” koji slijede pružit će im protutežu i upotpuniti ih onom drugom, intimnom i emotivnom dimenzijom.

Osebujan i svestran, Benešić je bio književnik, književni i kazališni kritičar, prevoditelj, leksikograf i jezikoslovac. Za Poljsku se zainteresirao već u šestom razredu osječke gimnazije. Slučajno posudivši iz školske knjižnice Veber-Tkalčevićev prijevod djela Ignacyja Krasickog Pan Podstoli, u kojemu je nekoliko citata iz Psalma Jana Kochanowskog bilo ostavljeno u originalu s dodatnim prijevodom na hrvatski, bio je zapanjen sličnošću između našega i poljskoga jezika (P[etris] 1932: 213-214). Kako sam navodi, već je u šestom razredu počeo razmjenjivati pisma s poljskim kolegama ${ }^{2}$. Dopisivanje je preraslo u brojna prijateljstva i poznanstva, a odlaskom na studij u Krakov Benešić ulazi sve dublje u poljsku kulturu. God. 1912. utemeljio je zagrebačko društvo prijatelja Poljske „Ognisko Polskie”, 1918. radio je kao lektor za poljski jezik na zagrebačkom sveučilištu, a u Hrvatskoj enciklopediji bio je urednik za poljsku književnost. Od 1930. do 1938. boravio je u Varšavi kao kulturno-prosvjetni delegat tadašnjeg Ministarstva prosvjete, djelujući kao ambasador

${ }^{1}$ Rad donosi izbor iz korespondencije Julija Benešića i Zdenke Marković koja se sastoji od ukupno šezdeset pisama, razglednica i dopisnica napisanih između 1909. i 1952. godine. Korespondencija se čuva u njihovim rukopisnim ostavštinama pohranjenima u Arhivu Odsjeka za povijest hrvatske književnosti Zavoda za povijest hrvatske književnosti, kazališta i glazbe HAZU u Zagrebu. U priređivanju građe korišteni su prilozi Ivana Medena Rukopisna ostavština Julija Benešića i Popis pisama upućenih Zdenki Marković objavljeni u „Kronici Zavoda za književnost i teatrologiju JAZU” (v. Literatura), uz nekoliko izmjena, budući da je, uglavnom prema sadržaju, bilo moguće kronološki odrediti nekoliko razglednica i pisama koji u Medenovim popisima nisu bili datirani.

${ }^{2}$ „Koliko i kako sam nekada kao dječak čeznuo za tim gradom; kako sam pomno precrtavao njegov plan iz Meyerova leksikona, skupljao karte sa slikama krakovskih zgrada!” (Benešić 1922: 33-34). 
hrvatske, ali i ostalih južnoslavenskih književnosti u Poljskoj, o čemu je i pisao u zapisima Osam godina u Varšavi. Tijekom boravka u Varšavi, dijelom vlastitim sredstvima, a dijelom uz financijsku pomoć Ministarstva prosvjete te poljskog industrijalca hrvatskog podrijetla Leona Halbmilliona, pokrenuo je Biblioteku Jugosłowiańsku u kojoj su objavljivani prijevodi djela hrvatskih, srpskih i slovenskih književnika, poput Ivana Gundulića, Ivana Mažuranića, Ivana Vojnovića, Miroslava Krleže, Petra Petrovića Njegoša, Ivana Cankara i dr. Ipak, Poljsku nije smatrao drugom domovinom, kao što mnogi vole isticati ${ }^{3}$. U Poljskoj je bio član nekoliko kulturno-umjetničkih društava i odbora Lige poljsko-jugoslavenskih društava, odlikovan je poljskim zlatnim križem za zasluge (1946.). Već 1898. počeo je prevoditi poeziju Adama Mickiewicza i Juliusza Słowackog. Od prvog tiskanog prijevoda 1901. - Priviđenja Bolesława Prusa - nastavio je neumorno prevoditi uglavnom dramska djela poljskih pisaca te ih kao intendant Narodnog kazališta (1921.-1927.; 1939./1940.) postavljati na zagrebačku scenu. Uredio je i dijelom preveo prvu poljsku antologiju na hrvatskom jeziku Poljska lirika (1939.) ${ }^{4}$. Posebno poglavlje u Benešićevu opusu zauzima leksikografski i jezikoslovni rad: u Varšavi je 1937. objavio gramatiku hrvatskog ili srpskog jezika na poljskom (Gramatyka języka chorwackiego czyli serbskiego), 1949. u Zagrebu Hrvatsko-poljski rječnik (Poljsko-hrvatski rječnik ostao je u rukopisu), a surađivao je i na Akademijinu Rječniku hrvatskoga književnog jezika. Benešićevo nevjerojatno zalaganje za promicanje hrvatske polonistike Poljaci su opravdano nagradili: dodijeljen mu je počasni doktorat filozofskih znanosti Jagiellońskog sveučilišta u Krakovu (1948.) i prevoditeljska nagrada poljskoga PEN-kluba.

${ }^{3}$ „Putovanje zacielo ima svoj čar, ali pravi mu smisao daje samo nada u povratak - kući. Bio sam mnogo godina izvan domovine, a mnogo više izvan rodne kuće, i mogu reći, da misao na domovinu u tuđini i na rodni dom djeluje kao utjeha u tuzi i kao obuzdanje nekih sklonosti, koje se buntovno javljaju u srdcu, pa ta misao kao neka savjest šapće: pazi, što bi rekli tvoji kod kuće, da to učiniš? - To je moral našega doma. Mnogo sam vremena proživio u Poljskoj. Netko mi u nekoj zdravici reče, da mi je to druga domovina. Smiešno! Kao da je to moguće. Domovina može biti samo jedna, ili nijedna..." (Benešić 1943: 8; cf. Matković 1968: 10).

${ }^{4}$ Preveo je osamdesetak djela iz poljske, njemačke i ruske književnosti za Zabavnu biblioteku N. Andrića i Maticu hrvatsku. O Benešićevim prijevodima s poljskog više u Batušić 1977: 33-34 i Paździerski 2004: 159-196. 
Književni opus Zdenke Marković obuhvaća poeziju, kratku prozu i memoarske zapise, a uspješno se bavila i znanstveno-stručnim radom pišući članke, oglede i studije iz književnosti i povijesti umjetnosti. Cijeli je život radila na zbližavanju hrvatskih i poljskih intelektualki, a prema vlastitim riječima, poljski je počela učiti kao licejka, sedmoškolka, potaknuta inspirativnim predavanjima prof. dr. Josipa Florschütza (Kuntarić 1973: 3). Nakon završetka sedmog razreda, za vrijeme školskih praznika kod bake u Pleternici, počela je uz pomoć rječnika i gramatike ovladavati poljskim jezikom (Marković 2007: 424-425). Nakon mature na Ženskom liceju 1901. studirala je slavistiku (ruski i poljski jezik), filozofiju i povijest umjetnosti. God. 1912. posjetila je Krakov prigodom svečane proslave 100. obljetnice rođenja poljskog pjesnika Zygmunta Krasinskoga. U Klubu Słowiańskom održala je predavanje na poljskom o suvremenim hrvatskim književnicama i tada je upoznala i Henryka Sienkiewicza i Stanisława Wyspiańskoga. Iduće godine nastavila je studij polonistike u švicarskom Fribourgu, gdje se družila s Poljakinjama koje su također ondje studirale. Slušala je predavanja iz slavistike, specijaliziravši se za poljsku književnost kod prof. Stanisława Dobrzyckoga, pročelnika katedre za poljski jezik i književnost. Stoga je i za temu doktorske disertacije (1914.) odabrala djelo poljskog dramatičara, pjesnika i slikara S. Wyspiańskog ${ }^{5}$. Na poziv poljskog Ministarstva vanjskih poslova posljednja tri mjeseca 1922. boravi u Varšavi, a od 22. kolovoza do 1. listopada 1936. sudjeluje na Međunarodnom kongresu akademski obrazovanih žena u Krakovu. Radom u zagrebačkom Poljsko-jugoslavenskom društvu, predavanjima i prijevodima s poljskog ${ }^{6}$ te studijama i člancima o poljskim autorima, kao i osvrtima na njihova djela u domaćoj i poljskoj periodici, ostavila je nezaobilazan trag u hrvatskoj polonistici, za što je 1928. odlikovana ordenom Polonia Restituta, a 1974. primila je i priznanje poljskog ministra kulture za promicanje poljske kulture i umjetnosti.

${ }^{5}$ God. 1924. objavljen je prijevod disertacije s njemačkog na poljski jezik: Pojęcie dramatu u Wyspiańskiego.

${ }^{6}$ Ignacy Maciejowski Sewer, Ljepota djevojka, Zagreb, 1917.; Maria Konopnicka, Izabrane novele, Zagreb, 1920.; M. Konopnicka, Madame la Vierge (Na normandijskoj obali), Zagreb, 1922.; Edward Ligocki, Noć na Palatinu, Zagreb, 1925.; Antoni Józef Gliński, Poljske narodne pripovijetke, Zagreb, 1926.; Adolf Dygasiński, Blagdani života, Zagreb, 1931.; Z. Nałkowska, Zla ljubav, Zagreb, 1932.; Ferdynand Ossendowski, Milijunar "Y”, Zagreb, 1933.; Kornel Makuszyński, Čovjek nađen u vreći, Zagreb, 1944.; Ferdynand Ossendowski, Doživljaji Jurice u Africi, Zagreb (s. a.). 
Čitajući sadržajno raznovrsnu korespondenciju J. Benešića i Z. Marković, otkriva nam se cijeli niz zanimljivosti iz njihova javnog i privatnog života - no ne samo njihova. Zabilježena su tu i mnogobrojna imena raznih osoba iz kulturnih krugova koje su na ovaj ili onaj način ostavile traga u njihovim životima. Najčešće se spominju osobe koje su (od)igrale važnu ulogu u hrvatsko-poljskim književno-kulturnim vezama prve polovice dvadesetog stoljeća: poljska pjesnikinja i novinarka Kazimiera Alberti, poljska spisateljica Zofia Nałkowska, poljski književnik Mieczysław Smolarski, liječnica Bronisława Prašek Całczyńska, poljski slavist i prevoditelj Bronisław Grabowski i dr. Literarne teme bile su, naravno, neizbježne. Benešić gotovo stidljivo šalje $Z$. Marković svoje stihove, moleći je da iznese svoj sud, ali pod trima uvjetima: „ne pokazujte”, „ne kazujte” i „molim da mi to vratite". Oni su 1922. godine objavljeni u zbirci Istrgnuti listovi, a u predgovoru Benešić potvrđuje osjećaj otuđenosti od vlastite lirike koji se već naslućuje u jednom od pisama Z. Marković (15. ožujka 1917.):

Istrgnuti ste iz dnevnika, koji je bio pisan samo u ljubavi i jačoj još mržnji, u samoći; istrgnuti ste, a iza vas ostade još rpa papira ispisana zgrčenim slovima triumfa i očaja. Kakvu imate vrijednost za druge, ne hajem, - za mene ste imali cijenu najmilijih uspomena. Sada ste mi tudji i daleki kao što je dalek trag, što ga je ostavila Zemlja onih dana i onih noći (Benešić 1922: 7).

U pismima nalazimo i traduktološke teme (Benešićevo pismo od 24./26. veljače 1917.), što nimalo ne čudi, s obzirom na već spomenutu važnost prevođenja u Benešićevu opusu ${ }^{7}$, ali i književno-kulturnom radu Z. Marković. Stoga, bez obzira na povremene naznake simpatije i dublje emocionalne povezanosti ${ }^{8}$, pa i napetosti ${ }^{9}$, glavna dodirna točka njihova prijateljstva, i lajtmotiv koji se provlači korespondencijom, ostaje upra-

${ }^{7}$ Benešić je prevođenje smatrao stvaralačkim činom, jednakim stvaranju originala, a njegovo shvaćanje samoga procesa prevođenja možda najbolje ilustriraju ove rečenice: „Ako ne mogu dati dobro svoje djelo, volim prevesti tuđe. To je razlog zašto sam toliko prevodio, no to je i pitanje: jesam li to dobro učinio. Mislim da nisam uvijek” (Paździerski 2004: 141).

${ }^{8}$ „Uostalom, odavno već osjećam, kako je čudno nešto, što stoji među nama; jest nešto, što nas privlači, a i isto toliko odbija. (...) Odgovorite prijateljski (uostalom, jesmo li mi prijatelji, gdjekad mi se čini, da smo manje, a gdjekad mnogo više od toga)... " (pismo Z. Marković, 16. svibnja 1922.)

${ }^{9}$ Čini se da je Benešić zamjerio Z. Marković što mu nije poslala primjerak svojega Leta, pa joj 19. svibnja 1922. dosta hladno odgovara: „Volim masku, ali ne volim stidljive istinice”. 
vo polonistička odnosno polonofilska nit. Primarno što ih povezuje jest Poljska: poljska kultura, poljska književnost, prijateljstva i poznanstva s mnogim Poljacima. Razmjenjuju se dojmovi i iskustva iz posjeta Poljskoj, primjerice, s Kongresa prijateljstva koji se održao od 25. travnja do 3. svibnja 1931. uz obilazak Poznanja, Gdinje, Varšave i Krakova ${ }^{10}$.

Jezik ovih pisama, međutim, svjedoči i o različitosti karaktera Zdenke Marković i Julija Benešića: njezina energičnog, društvenog i otvorenog, njegovog povučenijeg, suzdržanijeg i introvertnog. Primjerice, u pismu od 19. ožujka 1917., Z. Marković daje osvrt na Benešićeve pjesme, pitajući ga: „Jeste li Vi u životu mnogo trpjeli?” Odgovor na ovo pitanje nismo pronašli, barem ne u sačuvanoj korespondenciji ${ }^{11}$. Benešićeve su rečenice, za razliku od emotivnije nabijenih Zdenke Marković, većinom pisane odmjerenim, katkad gotovo službenim tonom ${ }^{12}$. Iz gotovo svake riječi iščitava se potpuna predanost radu, čemu u prilog govori i Matkovićev dojam o Benešiću: „A on (Benešić, op. prir.) je radio sam, vječno u svom momačkom stanu, okružen knjigama i mačkama, osamljen kao pustinjak a opet uvijek tako živo prisutan u našoj kulturi” (Matković 1968: 9), kao i Peićev slikoviti opis Benešićeva stana u jednokatnici na Ilirskom trgu u doba kad

${ }^{10}$ Osim promjena zagrebačkih adresa (Z. Marković stanovala je u Preradovićevoj 29, Visokoj 16, Jurjevskoj 19 i Dežmanovom prolazu 3, a J. Benešić u Prilazu 15, Prilazu 23, ul. Mošinskoga 34 i naposljetku na Ilirskom trgu 8 na Gornjem gradu), zanimljivo je putem pisama pratiti itinerer njihovih putovanja. Z. Marković posjetila je ili duže boravila u Videmu (Štajerska), Kranjskoj gori, Fribourgu (Boulevard de Péralles 16, Swisse), Ujvidéku (Novom Sadu), Varšavi, Zakopanim (Tatry), Šibeniku i Logarskoj dolini, a Benešić u Ženevi, Kölnu, Iloku (Srijemu), Pragu, Krakovu, Varšavi (ul. Hoża 18), Białowieżi...

${ }^{11}$ Benešić i Markovićka susretali su se i razgovarali i uživo (,,Mogla sam to i usmeno reći, ali nisam htjela, jer često usnice i nehotice kažu nešto drugo, nego što bi čovjek htio da kaže. Suviše su brbljave i bučne", pismo Z. Marković, 19. ožujka 1917.), kao i telefonski, no iz razdoblja neposredno prije i nakon Drugoga svjetskog rata (1938.-1947.) nije sačuvano nijedno pismo.

${ }^{12}$ Vidljivo je to i iz oslovljavanja na početku te pozdrava na kraju pisama. Z. Marković Benešića oslovljava s ,,wielmożny Pan; monsieur; štovani gospodine, gospodin profesor, dragi gospodine Julije; dragi moj Julije”, a on nju s ,,velecijenjena/veleštovana/visoko poštovana gdjica; mademoiselle; draga gospođo Zdenka/Draga zacna Pani”, iako ga ona u pismu od 26. listopada 1930. čak moli da joj se ne obraća tako službeno. Benešić pisma završava s „Vaš odani/Srdačan pozdrav uz rukoljub/Rukoljub/Uz rukoljub Vaš/preporučam Vam se uz najsrdačniji pozdrav/Srdačno Vas pozdravlja Vaš/Vaš Julije, a Zdenka Marković uglavnom bliskije i toplije: „Najsrdačnije Vas pozdravlja/primite mnogo lijepih pozdrava od Vaše/Srdačno Vas pozdravlja/Mnogo toplih pozdrava/mnogo Vas pozdravlja i ljubi Vaša Zdena”. 
je Benešić radio na Rječniku hrvatskoga književnoga jezika: „Onaj mali dekor sobe: snijeg na slici jednog poljskog slikara smještenoj iznad bijelih vrata spavaonice, Valdecova bista Lunačeka, litografija Benešićeva rodnog gradića Iloka iznad stola za pisanje, slika jednog davnog mačka Benešićeva ljubimca malog Romča, nekoliko cvjetova na prozoru..." (Peić 1956: 4).

Praktički vršnjaci, Julije Benešić i Zdenka Marković svojom su stvaralačkom energijom obilježili prvu polovicu dvadesetog stoljeća u hrvatskoj polonistici. Djelići mozaika iz ovih dvojezičnih pisama i razglednica koje su razmjenjivali tijekom četrdeset tri godine na svoj način omogućuju stvaranje cjelovitijih predodžbi ne samo o njihovu kulturno-književnom radu i ondašnjem općem kulturnom ozračju, nego i o njima kao osobama.

\section{Literatura}

Batušić S., 1977, Prijevodi Julija Benešića prikazivani u HNK-u u Zagrebu, u ostalim kazalištima te sačuvani u rukopisu, „Kronika Zavoda za književnost i teatrologiju JAZU" br. 2, str. 33-34.

Benešić J., 1922, Istrgnuti listovi, Zagreb.

Benešić J., 1922, Razgovori, Zagreb.

Benešić J., 1943, Autobiografija, „Hrvatska pozornica” br. 12, str. 8.

Kuntarić Đ., 1973, Dr. Zdenka Marković - najstariji živi hrvatski polonist, p.o. „Požeškog zbornika" br. 4, str. 1-13.

Marković Z., 2007, Njegov posljednji san. Iz ostavštine, prir. H. Sablić-Tomić, Požega.

Matković M., 1968, Julije Benešić i hrvatska književnost prve polovine XX. stoljeća, p.o. knjige Simpozij „Doprinos Slavonije hrvatskoj književnosti”, Vinkovci-Zagreb, str. 5-11.

Meden I., 1977, Rukopisna ostavština Julija Benešića, „Kronika Zavoda za književnost i teatrologiju JAZU" br. 2, str. 35-138.

Meden I., 1978, Korespondencija Julija Benešića s Poljacima, „Kronika Zavoda za književnost i teatrologiju JAZU" br. 8, str. 88-138.

Meden I., 1981, Popis pisama upućenih Zdenki Marković, „Kronika Zavoda za književnost i teatrologiju JAZU" br. 20, str. 63-74.

Paździerski L., 2004, Julije Benešić i Poljaci, Zagreb.

Peić M., 1956, Književnik i lingvist. Razgovor s Julijem Benešićem, „Narodni list” br. 3566 , str. 4.

P(etris) H., 1932, Književno-kulturni rad Julija Benešića, „15 dana: kronika naše kulture" br. 14, str. 213-214. 
(B-M; PISMO s kuvertom, Zagreb, 5. ožujka 1909.)

Veleštovana gdjice!

Uslijed nagle i nenadane prehlade slobodan sam javiti Vam, da mi danas nije moguće govoriti poljski. U nadi, da mi ne zamjeravate, kličem Vam: do vidjenja na „Krizi” u subotu u kazalištu, kamo ćete jamačno s gospodjicom sestrom doći. Tom ćemo zgodom moći istaći svoju superiornost nad hrvatskim općinstvom govoreći tim jezikom. Još jednom molim za oproštenje! S veleštovanjem jesam

(Julije Benešić) $^{13}$

Zagreb, 5/3 09

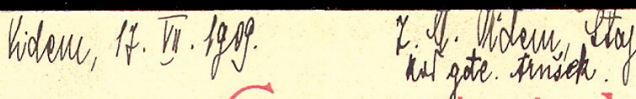

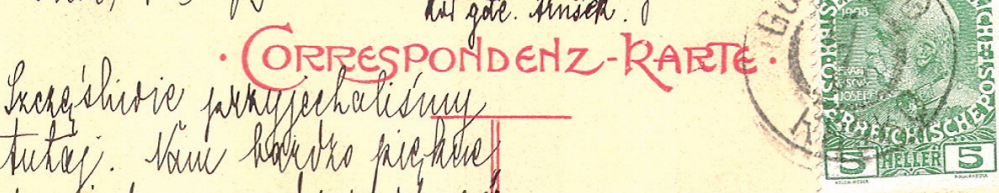

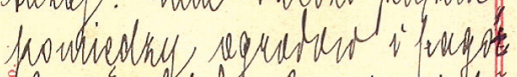

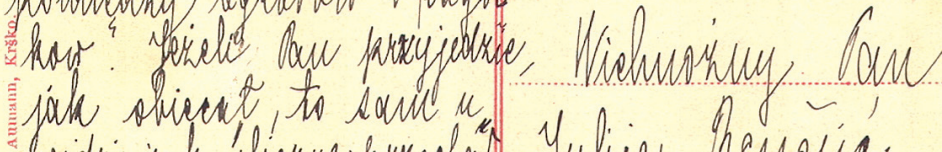

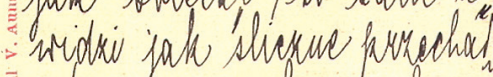

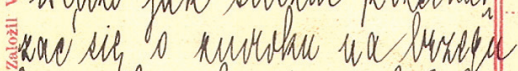

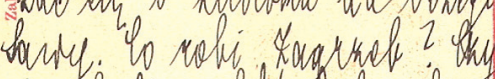

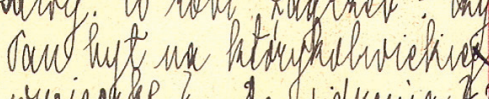

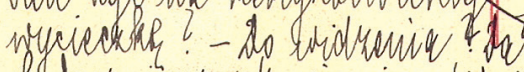

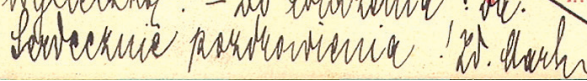

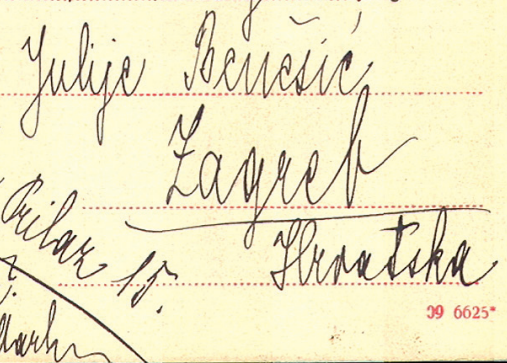

${ }^{13}$ Već otisnuto na kartici, op. prir. 


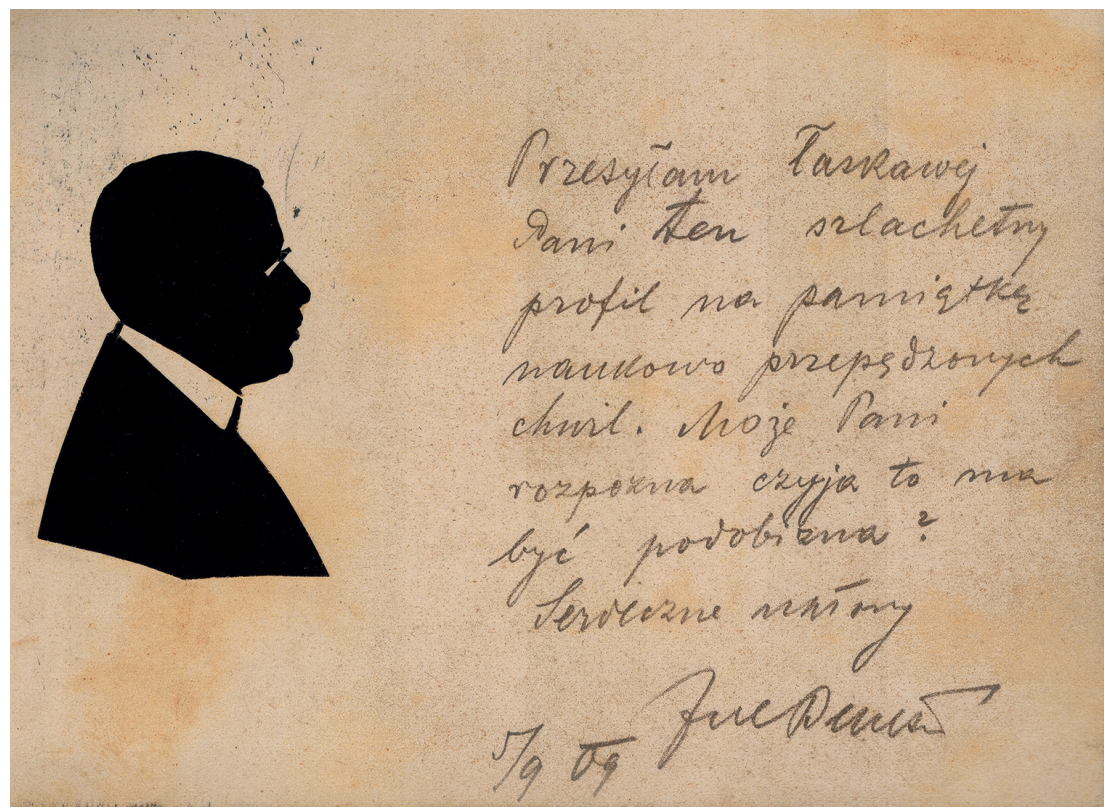

(M-B; RAZGLEDNICA, Fribourg, 10. veljače 1913.)

Sigurno ste već čuli, da sam tako sretna i da sam ovdje u Švicarskoj. Vrlo mi je lijepo; taj sredovječni grad pobuđuje sve najljepše u duši čovjeka. Inače na sveučilištu imam dosta posla. Poljska su predavanja zanimiva, osobito Wysp. Uopće, tu je „mala Poljska” - sva sila Poljaka. - Kako je inače? Zagreb - čini se - kao obično - drijema.

Mnogo srdačnih pozdrava

Zdenka Marković

(B-M; PISMO s kuvertom, Zagreb, 6. svibnja 1915.)

Visoko poštovana gospodjice,

Primio sam s najvećim ushićenjem i zahvalnošću Vašu knjigu „Der Begriff des Dramas bei Wyspiański" i najsrdačnije Vam zahvaljujem čestitajući Vam tom prilikom na doktoratu. Čast mi je, što ste me nazvali 
„učiteljem” poljskoga jezika, a nenadana je - skoro bih rekao - telepatija mene ponukala, da sam, dok ste Vi svoju radnju štampali, prevodio „Warszawianku” i „Boleslava Smjelog”"14.

Izvolite, ,učenice”, primiti najsrdačniju hvalu, jer evo već i ,učitelja” natkriliste, što bi rekao Krist.

Uz pozdrav Vaš odani Jul. Benešić Zagreb, 6/V 1915.

(B-M; PISMO bez kuverte, Zagreb, 24./26. veljače 1917.)

Visoko poštovana gospodjice!

Evo Vam šaljem svoj prijevod onih mjestâ, što ste mi označili u knjizi i na papiriću. Samo sam one stihove na str. 51 i 55. preveo u srokovima, no i tu ćete vidjeti, da sam se zbog toga morao dosta udaljiti od teksta originala. Słowackoga ${ }^{15}$ inače (izvatke iz „Szwajcarye” i „Balladyne”) preveo sam bez srokova, samo u ritmu, jer bi srokovi iznakazili original, a i bez srokova je prijevod blijed, jer je naš jezik brbljav, homerski dugačak prema kratkom poljskom izrazu i prema njihovim kraćim formama u konjugaciji i deklinaciji. Nisam ni pomislio, da bi se to moglo s rimama prevesti, jer bi u našem jeziku to zvonilo kao Trnskovi prijevodi i bilo bi to „trnskimice” prevedeno, t. j. nitko ne bi razumio smisla duboke poezije Słowackoga.

Evo po redu:

str. 1) „Sudba je moja: kraljevati u snu, S harfama niemim ${ }^{16}$, slušačima gluhim”.

str. 51) ,Jadni puk sam zavolio, Pjesmu mi je on u zipci dao, Njegov govor, običaj mi mio,

${ }^{14}$ Warszawianka (Varšavljanka) i Bolesław Śmiały (Boleslav Smjeli) drame su poljskog dramatičara, pjesnika i slikara Stanisława Wyspiańskog (1869.-1907.), čiji je opus tema doktorske disertacije Z. Marković, op. prir.

${ }^{15}$ Juliusz Słowacki (1809.-1849.), poljski pjesnik, dramatičar i epistolograf, op. prir.

${ }^{16}$ Pišem ie umjesto “j; bolje je ,niemim” od „n’jemim”. (Benešićeva opaska, op. prir.). 
Jer sam ga sa mliekom usisao" ${ }^{17}$.

(...)

Želeći svako dobro, u nadi da ćemo se vidjeti skoro (možda u utorak?) preporučam Vam se uz najsrdačniji pozdrav

U Zagrebu, 24. II na dan sv. Matije 1917.

Jul. Benešić

P. S. Medjutim sam počeo čitati Sewerovu ${ }^{18}$ knjigu i zato nisam odmah poslao ovo. Pročitao sam i začas se prenio u milu okolicu krakovsku. Dodjite u utorak, sutra, u 6 sati u $\mathrm{DHK}^{19}+$ ), ali zacijelo.

\section{Rukoljub}

\section{Benešić}

$26 / 217$

(B-M; PISMO s kuvertom, Zagreb, 15. ožujka 1917.)

Visoko poštovana gdjice,

evo Vam šaljem na ogled i na uvid ove stihove ${ }^{20}$, kojih u cjelini nije još nitko čitao. Po formi ćete poznati, da su spremni za štampu, no nisu definitivno pregledani, jer ne znam, gdje bih ih štampao i da li bih ih uopće štampati dao.

Ne očekujem od Vas nikakovih konvencionalnih pohvala ni komplimenata, jer su mi ti stihovi doista tudji, strani, oni me se i ne tiču više, ma da nisam svoje naravi promijenio od onda do danas.

Oni su svi tkani na jedno brdo i zato su jednolični, neki dosadni, a neki nejasni. To, što su nejasni, krive su oči čitateljeve, a ne moje. Za mene su jasni, jer znam, o čemu te riječi govore, koga sam i što sam mislio. Da je

${ }^{17}$ Navodimo tek početak opsežnog prijevoda iz pisma, op. prir.

${ }^{18}$ Ignacy Maciejowski (pseud. Sewer), poljski pisac; njegov roman Ljepota djevojka prevela je s poljskoga Zdenka Marković, op. prir.

${ }^{19}$ Moj dodatak: DHK = Društvo hrvatskih književnika (Rukopis Z. Marković, op. prir.).

${ }^{20}$ Riječ je o pjesmama koje su 1922. godine objavljene u Zagrebu u zbirci Istrgnuti listovi, op. prir. 
tako, dokazuju braća ovih stihova (imam ih u ladici još jedamput toliko), no ti su doista samo za mene ne samo bili pisani, već su i ostali za mene ili za vatru. Oni nemaju formu za javnost, nemaju opremu za ulicu i bestidno su iskreni, infamno naivni i bezdano - moji. To su moji razgovori sa sobom, koji se čuvaju - a najčešće i ne čuvaju na papiru. Koliko sam ih napisao da sebe porazgovorim, a napisane, pročitane i nepročitane, bacio u peć.

Samo molim ona 3 uvjeta da pamtite:

1) ne pokazujte

2) ne kazujte $i$

3) sam zaboravio, no Vi ćete se od jučer još sjećati trećega uvjeta.

Molim - znam! - to je treći uvjet, molim da mi to vratite, jer je jedino, što imam. Uz rukoljub i pozdrav

JulBenešić

$\mathrm{Zgb}, 15 / 31917$

(M-B; PISMO s kuvertom i pečatom, Zagreb, 19. ožujka 1917.)

Ponedjeljak, 19.III.917.

Štovani gospodine,

Svaki put, kad pročitam čiju zbirku pjesama, tako mi je kao da sam ulovila živu dušu pjesnika. I eto tako me sada Vaša duša, koju sam kao nemirnoga leptira među stihovima uhvatila, prati već nekoliko dana na svim mojim putovima.

Neki dan sam sjedjela podveče kraj prozora i slušala pjesmu, što ju je vjetar i rano proljeće pjevalo oko jednoga osamljenog jablana šumskoga i ona - Vaša duša slušala je također. Uveče čitam i razmišljam, a ona mi razbija misli. (...) Ona mi je mila, ta Vaša duša, koja mi je dosad bila nepoznata. Vjerujte mi, da sam se u posljednje vrijeme, otkad smo se opet nekako u životu sreli, dosta razmišljala o Vama i odlučila, da Vas jednom upitam: tko ste uistinu?

Nisam bila nikad na čistu. Jednom ste imali nešto ko bezbrižno, zadovoljno dijete, drugi put ironiju čovjeka, kojega je život za nešto prevario, onda je opet bilo nešto hladno i suviše trijezno u Vama. Sad Vas poznam i tako mi je drago. 
Držala sam Vas za nekoga drugog, za čovjeka zadovoljnoga, mirnog i trijeznog, možda nešto nestašnoga i razmaženog, pa nisam mislila, da se iza Vaše mirne površine buni i vrije u Vama duša ko u mnogima nama, da vječno gradi i ruši nevidljive svjetove. Ipak je čudno, kako se često ljudi, koji se dulje vremena znadu, ipak ne poznaju.

Zato Vam najljepše hvalim za pjesničku pošiljku Vašu, osobito za one posljednje stranice.

A sada na pjesme.

Prije svega su iskrene; osjeća se, da su pisane za Vas bez obzira na išta i ikoga. Osvajaju iskrenošću i jednostavnošću. (...) Neke od njih slabije su prema ovima, padaju u snazi, djeluju jednolično (...). Držim, da bi bila posve lijepa zbirka. Imadu sve u sebi nešto zdravo i vedro. — Jedno bih htjela znati, jeste li Vi u životu mnogo trpjeli? Razumijte me dobro. Ima ljudi, koje doživljaji promijene, prignu, ugnjetu, unište, ako hoćete, ali oni ne trpe, ne osjete nikada onu veliku bol, iza koje se čovjek diže i preporađa; koja je doduše grozna, ali je lijepa. Svaka velika bol čini čovjeka boljim. Eto, o toj boli govorim sada i na takvu trpnju mislim.

Vi ćete mi oprostiti moju iskrenost i otvorenost. Pišem danas eto upravo ono, što bih sama sa svojom dušom govorila. Mogla sam to i usmeno reći, ali nisam htjela, jer često usnice i nehotice kažu nešto drugo, nego što bi čovjek htio da kaže. Suviše su brbljave i bučne.

Vaših sam se uvjeta držala posve točno. Nemajte brige, Vaše su pjesme zatvorene i zaključane u ladici moga pisaćega stola. Danas ih ne vraćam, jer se bojim, da se ne zametnu ili ne izgube, hoću, da Vam ih predam u ruke. O tom se možemo dogovoriti. Ja svršavam jednu novelu, koju bih htjela kod sebe u malom krugu pročitati. Molit ću i Vas da dođete, pa ih onda možda možete ponijeti.

Srijedu po svoj prilici neću moći doći u D.H.K. Idete li možda sutra (utorak) u kazalište na Ibsena? Iza dugog vremena ćemo ga opet gledati. Posve se veselim na tu predstavu.

Završujem. Možda sam bila i suviše iskrena.

Najsrdačnije Vas pozdravlja 
(B-M; RAZGLEDNICA, Krakow, 23. studenoga 1920.)

Krakov, 23/11 1920

Nalazim se u ovom posve istom starom gradu i pozdravljam Vas moleći za oproštenje, što Vam tim sjećanjem možda smetam u Vašem miru. Ja sam vrlo zaposlen i vrlo umoran.

JulBenešić

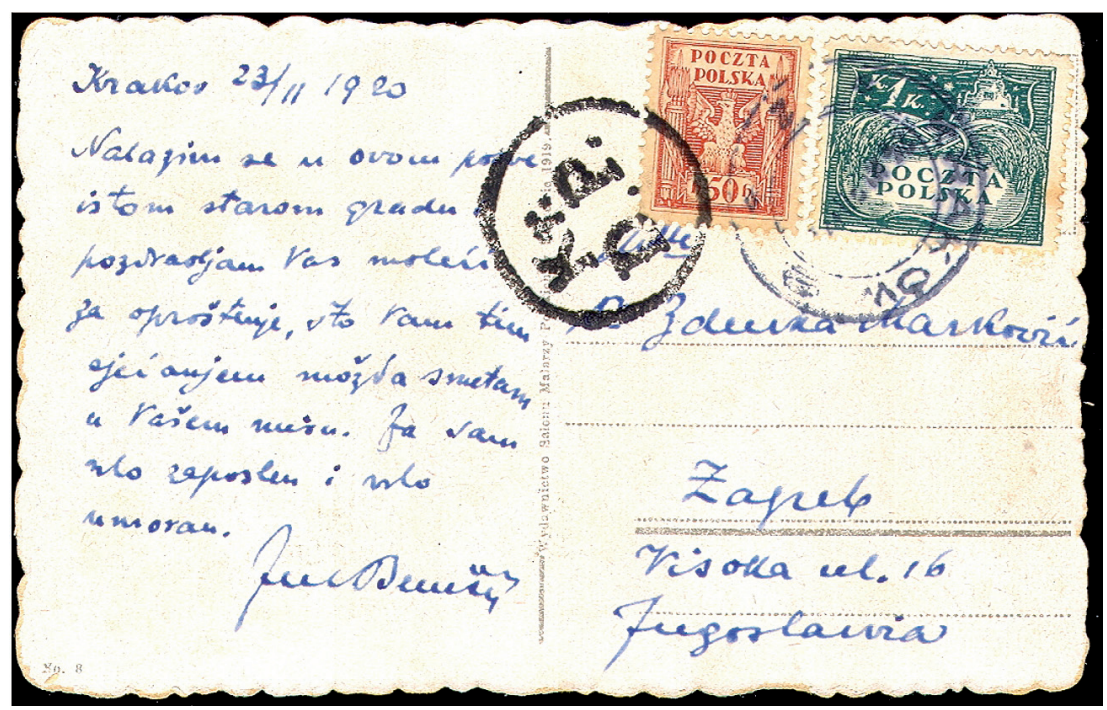

(B-M; PISMO s kuvertom, Zagreb, 28. svibnja 1921.)

Draga gdjice Zdenka,

zahvaljujem na sjećanju i čestitci. Da sam znao, da ste tu, zamolio bih Vas, da prisustvujete jučer Kletvi Wyspiańskoga i večeri priredjenoj u počast Wysockoj ${ }^{21}$, koja je jutros otputovala. S pozdravom Vaš

JulBenešić 28/5 1921

[Pismo je napisano na poleđini posjetnice; na drugoj strani je otisnuto:]

${ }^{21}$ Stanisława Wysocka, glumica, op. prir. 


\section{Prof. Julije Benešić \\ intendant Narodnog Kazališta u Zagrebu}

(M-B; PISMO s kuvertom i pečatom, Zagreb, 16. svibnja 1922.)

Dragi gospodine Julije,

Zgb., 16. maja 922.

Od one večeri, kad smo bili zajedno, pa sve do danas, muči me čudni neki osjećaj (uostalom nimalo stran, ponovi se svaki put, kad se sretnemo, možda već dvije godine), osjećaj, da smo jedno drugom nešto krivi, ili, ni to nije možda pravo, kao da sam ja samo Vama nešto skrivila, ili nešto tako slično. Osjećaj je to neugodan i muči me. Uostalom odavno već osjećam, kako je čudno nešto, što stoji među nama; jest nešto, što nas privlači, a i isto toliko odbija. Sve se to ne da ni riječima izreći, tek u meni je kaos misli i osjećaja. Ili eto ovo; već godine vidim u polusvijesti tu sliku: nas se dvoje vozimo na nekoj željeznici i dalje ništa. Ni kuda, ni kada, ni je li lijepo, ništa dalje ne znam. Tek se vozimo. I bezbroj tako drugih čudnih stvari. Nisam dosad nikad htjela da diram u to, ni da prstom maknem, da se što promijeni. Sada me to najednom od neki dan muči; tako bih voljela znati, da li Vi išta o svemu tome znate po sebi i iz sebe. Ne mogu da vjerujem, da je sve to niklo samo u meni i da nimalo nije zahvatilo i Vas; pogotovo ne stoga, jer ima u nama toliko slična. A opet, nešto je napeto među nama, duše mi, gdjekad mi se čini, da će nešto da prsne oko nas, ili u nama, ili bog bi znao, gdje.

Ima nešto tako lijepo u svemu tome, a opet je nešto, što neizrecivo muči. Nije li tako?

Odgovorite prijateljski (uostalom, jesmo li mi prijatelji, gdjekad mi se čini, da smo manje, a gdjekad mnogo više od toga) i primite mnogo lijepih pozdrava od

Vaše

ZdM.

(B-M; PISMO bez kuverte i zaglavlja, Zagreb, 19. svibnja 1922.)

Mjesto odgovora na Vaše pismo od 16. ov. mj. šaljem Vam ovu knjigu ${ }^{22}$, da vidite, da li smo daleko. Vi ste osjećali, da jesmo, kad mi ne doletjeste

${ }^{22}$ Ovo „pismo” koje se čuva u korespondenciji, zapravo je Benešićeva posveta Zdenki Marković napisana na prvoj stranici njegove knjige Istrgnuti listovi, koju joj je, kako i sam piše, poslao kao odgovor na njezino pismo od 16. svibnja 1922. U primjerku Istrgnutih listova 
svojim „Letom”. No, mi se ne vozimo istim vlakom i nije nas isti potjerao vjetar. Volim masku, ali ne volim stidljive istinice.

Uz rukoljub Vaš

JulBenešić

Zgb, 19/V 1922

(M-B; PISMO s kuvertom, Zagreb, 21. svibnja 1922.)

Dragi gospodine Julije,

Zagreb, 21. V. 922.

Srdačna Vam hvala na Vašim listićima, koji mi se vrlo sviđaju. Čini mi se, po njima baš, da se ipak vozimo jednim vozom, samo kao ponešto strani putnici. Nije mi jasno, što znače one ,stidljive istinice”, bit će, da se to ima na mene da odnosi. Je li? Po tome vidim da smo zbilja strani. Kad pročitate moj Let, što ću Vam ga ovih dana poslati (učinila bih to odmah, ali nemam uza se više nijednoga egzemplara) držim, da ne ćete misliti tako. Velite, da volite masku. Ja je ne volim, jer ona malo sakriva, mnogo mi je miliji sredovječni željezni oklop, u koji se čovjek od glave do pete sakrije, pa tko će onda da ga pozna.

Mnogo pozdrava

ZM.

12/I 29

(M-B; PISMO s kuvertom, Zagreb, 12. siječnja 1929.)

Subota, 1929.

Eto, dragi moj Julije, ovo nekoliko riječi mjesto telefona. Vaša Zdena leži bolesna (nemam gripu, ne bih onda ni pisala, već neki kašalj uz malu temperaturu) i misli na Vas. Možda i Vaše misli kruže danas oko mene, ta toliko sam se puta uvjerila, da imamo oboje savršene antene, koje love naše misli. (...)

iz fonda osobne biblioteke Z. Marković, koja se čuva u knjižnici Odsjeka za povijest hrvatske književnosti HAZU, nedostaje upravo taj list! Op. prir. 
Silno volim zimu i snijeg, i ovaj oštri zrak, koji nosi neku vedrinu i ugodnost; zimsko sam dijete (čini mi se, da ste i Vi zimi rođen?!), pa uživam valjda zato u zimi. Vi doduše ne volite šetnje, ali to naše hodanje ne će biti šetnja, već ćemo učiniti da bude posao s nekim ciljem. (...)

Dajte mi se malo javite i napišite koju riječ. Tako smo zapravo blizu, preko dvije šume samo, a koliko treba, dok si nešto kažemo!

Mnogo Vas pozdravlja i ljubi

Vaša Zdena.

(B-M; RAZGLEDNICA, Varšava, 28. ožujka 1930.)

Draga zacna Pani!

Warszawa 28/III 30

Ovdje svakoga dana pitaju, kad ćete doći. Ja velim: na ferije. Lažem li? Ovdje je tako zima, da će u julu biti kao kod nas u proljeće, zato je bolje doći ovamo nego u Kranjsku. Ljubi Vam ruke i srdačno Vas pozdravlja

JulBenešić

(B-M; PISMO s kuvertom, Varšava, 14. travnja 1930.)

Mnogo poštovana i zacna,

wybitna przyjaciółko!

Hvala Vam na karti! Odgovaram odmah, premda ste samo jedno pitanje zapravo stavili: gdje je ta ul. Hoża? Ona je na zapad od Trga Trzech Krzyży, gdje su uostalom samo 2 križa, a ne 3. Paralelno sa Wspólnom i Zórawiom.

Nadalje Vam pišem, da Vam zaželim sretan Uskrs i svako dobro u ovom proljeću.

Konačno Vam pišem, da Vam najavim, da će prvih dana maja, možda već 2. ili 3. maja doći u Zgb gđa Kazimiera Alberti. Dao sam joj Vašu adresu i molim Vas, da joj u interesu naše stvari pomognete u čemu možete i koliko znate. Ona sa svojim mužem izdaje Slavensku Biblioteku u poljskim prevodima (prozu i stihove) i izdali su dosad nekoliko krasnih čeških edicija u poljskom jeziku. Sada su odlučili da isto učine s hrvatskim i srpskim djelima. Ona zato putuje u Zagreb, Beograd itd. i zanima se i za 
literaturu i za arhitekturu i za etnografiju. Visoko obrazovana i simpatična dama. Molim Vas zato, da joj pomognete, koliko znate i možete. (...)

Još jednom sretan Uskrs!

Javite se!

Ljubi Vam ruke

Vaš

JulBenešić

Warszawa 14/4 1930.

ul. Hoża 18, m. 6.

(M-B; PISMO s kuvertom, Zagreb, 22. travnja 1930.)

Uskrsni ponedjeljak 930.

Kochany Panie Juliuszu,

(...) Iz Obzorova feljtona Vašeg čini mi se, da se uza sve simpatije poljske ipak osjećate - sam. To mi je sasvim razumljivo, jer sam ja to za posljednjega svoga boravka 1922./23. silno osjetila. Okružena neprestano ljudima, dobrim i prijaznim, koji su me upravo mazili i na rukama nosili, ja sam se osjećala - sama. Neprijatno mi je bilo. I od onda vidim, da nije lijepo čovjeku u svijetu bez nekoga svoga. Drugo je, kad je čovjek onako mlad i lud, pa srce u svijetu i ne treba nikog, ali kad se u sebi sazori, pa je duša puna utisaka, sita od njih, onda treba neko bliz, da to prima i dijeli s njim. Nije li tako? Ja se sjećam, kako mi je prijatno bilo, kad ste me onda Vi dali po pokojnom Majerskom pozdraviti; ja sam se ludo razveselila, da mi se cijela ona kuća, tamna i neprijatna (možda i zato jer je bio oktobar) na Warzskoj 39 (čini mi se da je taj broj bio) od veselja razjasnila.

Molim Vas, pišite mi, što radite i čim se bavite, jer me to samu interesira, a i zato, jer se ljudi za Vas kod mene informiraju, kao da sam ja - ne znam - bolja ili lošija polovica Vaša. Ja sam - razumije se - ponosna na to baš kao i na Vas.

Duše mi, nekad je to bila moja sanja, da Vi dođete stalno u Poljsku, činilo mi se uvijek, kao da će se tim i moj neki problem riješiti. Čudan je onaj podsvijesni put i rad duše!

(...)

Mnogo Vas i srdačno pozdravlja Vaša 
(B-M; PISMO bez kuverte, Varšava, 7. listopada 1930.)

Visoko poštovana i draga gospođo!

Kod mene je bio G. dr. Mieczysław Smolarski, predsjednik Zrzeszenia Beletrystów polskich, i natuknuo mi je, kako mu je topla želja, da se neke njegove stvari prevedu na hrvatski. Ja sam mu rekao, da ja u Varšavi nikako ne dospijevam za taj posao, da bih event. mogao koju dramu prevesti, jer je to posao brz i za mene lak, no jer on ne piše drame, to mu je bila slaba utjeha. Onda sam mu spomenuo Vas i evo, poslao mi je svoje dvije knjige, koje Vam šaljem, s tom namjenom, da se prevedu ${ }^{23}$. Izvolite Vi, u ovim jesenskozimskim noćima, to pročitati i pokušajte staviti se u sporazum s drom Andrićem $^{24}$. Smolarski ne traži određenu sumu ili procenat honorara, ali svakako očekuje nešto, makar 100 zlotah, makar kakav dar u formi nekog našeg kurioziteta, svejedno. On se svakako sprema na godinu k nama. Smolarski je napisao više nego 20 knjiga, od kojih su neke izašle i u 3 izdanja, a druge, gotovo sve, u 2 izdanja. Nema sumnje, to je autor čitan. On je na čelu pomenutog Zrzeszenia i njegova je misao, da se pokrene književni Sporazum poljskočeškoslovačkojugoslavenski, o kojem sam Vam pisao i koji je trebao imati svoj kongres u Varšavi 3/11 zajedno s kongresom poljskojugoslavenskih društava u Ligi od Poznanja do Krakova, no koji - kako sam Vam javio - nije zbog parlam. izbora ostvario zasada. Odgođen je.

Molim Vas, pomozite našoj akciji i učinite što možete. Akcija je zamišljena vrlo ozbiljno i nema značaj momentarne manifestacije, nego trajnu i duboku vezu. Inače bi to bile besmislene parade kao što su po prilici PENklubske.

Javljaju mi, da ste se zauzeli za gđu Nałkowsku. U svoje Vam ime srdačno zahvaljujem, jer sam bio slobodan uputiti ju na Vas.

Srdačno Vas pozdravlja i ljubi Vam ruke Vaš

JulBenešić

Warszawa $7 / 1030$

ul. Hoża 18. m. 6

${ }^{23}$ Z. Marković na kraju se nije upustila u taj posao, a razloge navodi u pismu od 26. listopada 1930., op. prir.

${ }^{24}$ Nikola Andrić (1867.-1942.), prozaist, prevoditelj, urednik, književni povjesničar. Obnašao dužnosti predsjednika Matice hrvatske, Društva hrvatskih književnika i Društva prijatelja Poljske. Godine 1913. pokrenuo je i do smrti uređivao Zabavnu biblioteku u kojoj je objavio više od šest stotina djela iz svjetske književnosti, među njima i ona u prijevodu Z. Marković, op. prir. 
(B-M; RAZGLEDNICA, Poznanj, 18. listopada 1930.)

Poznań 18/10 30

Mnogo se i Vas spominjalo, draga i zacna prijateljice Poljaka, na današnjoj sjednici poljskojugosl. Lige. Kongres će biti početkom maja 1931. Ljubi Vam ruke

Vaš

JulBenešić

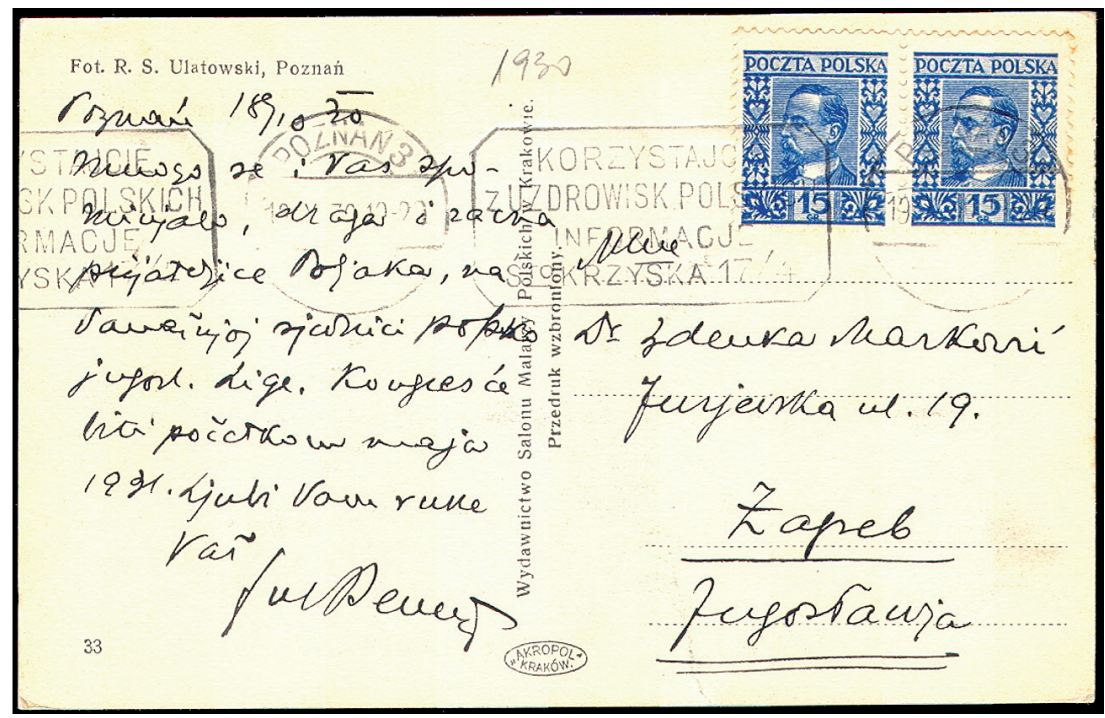

(M-B; PISMO s kuvertom, Zagreb, 26. listopada 1930.)

Zagreb, 26. X. 1930.

Dragi gospodine Julije,

Primila sam Vašu kartu i pismo iz Varšave, i nedavno kartu iz Poznanja; na svemu Vam srdačna hvala. Bila bih već prije pisala, ali sam najprije bila zaokupljena gđom Nałkowskom, a poslije me prignjavile naše žene iz nesretnih ženskih udruženja, koja iskreno mrzim iz dna duše, tako da sam jedno 14 dana živjela kao u nekom vrtlogu. Sad se to malo smirilo i ja (kao) slobodno dišem. Pitate, kako je bilo s gđom Nałkowskom? Vrlo lijepo, mi smo se vrlo dobro snašle; ona je inteligentna, zgodna žena, s kojom 


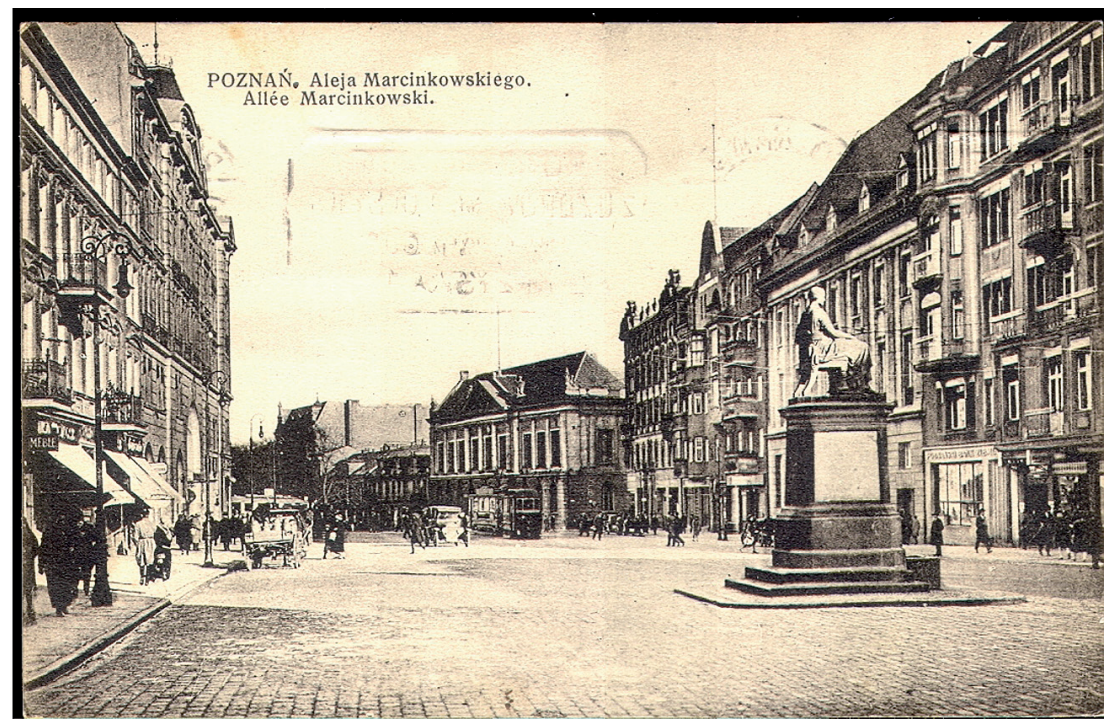

čovjek odmah nađe veza i dodirnih dotočaka. Sasvim se veselo onda živjelo. Neprestano čajevi, večere itd. Držim, da je i ona bila zadovoljna. Dogovorila sam se s drom N. Andrićem, da prevedem njen nagrađeni roman „Niedobra miłość”25, koji bi on izdao. Ona je obećala, da će mi to odmah poslati, međutim do danas nisam još ništa dobila. Vidite li je gdje možda, molim Vas da je potsjetite na njeno obećanje. Ja samo čekam da počnem. Eto, to je razlog (prvi), da ne mogu prevesti novele g. Smolarskoga, a drugo - među nama - ja takve stvari kao one dvije njegove - ne volim. To mi je oboje tako strano i daleko, da ne mogu ni pomisliti da bih nad tim sjedjela i gnjavila se prevodeći. Mene stvar treba da prije svega zanima i povuče - onda i prijevod ide. (...) Pozdravite lijepo u Varšavi sve, koji me se sjećaju! A Vas molim, da mi ne stavljate onako službene naslove u pismima kao posljednji put „visoko poštovana”, već me zovite kakogod hoćete, makar i „Zdena” kao u karti, premda baš nisam ,zdena”, kako se čini, naprotiv imam u sebi cijele vulkane (svezane) topline. Mnogo Vas i srdačno pozdravlja

Vaša Zdenka M.

${ }^{25}$ Zla ljubav, op. prir. 
(B-M; RAZGLEDNICA, Varšava, 31. listopada 1930.)

Warszawa $31 / 1030$

Draga g. Zdenka! Hvala na pismu od 26/10. Govorio sam s Nałkowskom, ali ne znam, da li Vam je poslala Niedobru miłość, jer je danas imala otputovati u Prag na svoju premijeru. Srdačno Vas pozdravlja i ljubi Vam ruke

Vaš JulBenešić

(M-B; RAZGLEDNICA, Zagreb, 5. studenoga 1930.)

Dragi g. Julije,

Zagreb, 5. XI. 930.

Upravo sam primila Vašu kartu i dan prije od g. Nałkowske knjigu „Choucas”. Sad stvar zbilja nije jasna! Prof. Andrić se dogovorio i s njom i sa mnom da se prevede „Niedobra miłość”, a ona mi šalje ovo drugo. Molim Vas, nije li se ona možda pred Vama u razgovoru izjasnila o tom ili je možda zaboravila, što smo u Zgbu dogovorili. Je li Vam ona što spomenula, što će se prevesti na hrvatski? Ne razumijem da mi onda nije poslala pravu knjigu! Mnogo Vas i srdačno pozdravlja

Vaša Zdena

(B-M; RAZGLEDNICA, Varšava, 9. studenoga 1930.)

Warszawa 9/XI 30

Draga g. Zdena, ja sam sinoć zamolio gđu Nałkowsku, da Vam pošalje „Niedobru miłość”. Obećala je, no za svaki slučaj, pišite joj i Vi. Ona je još uvijek ushićena Zagrebom i [nečitko] svog uspjeha u Pragu.

Srdačno Vas pozdravlja

Vaš

JulBenešić

(M-B; PISMO s kuvertom, Zagreb, 3. siječnja 1931.)

Dragi Julije, Zgb, 3. I. 931.

Napokon ćete dobiti pismo, koje sam Vam davno već trebala napisati. (...) 
Ne znam, jesam li Vam rekla hvala za Vašu intervenciju kod gđe Nałkowske. Ona mi je „Niedobru miłość” poslala i ja je prevodim. Radim to rado, jer je stvar pisana originalno; glavno je, zanima me. - Što je s onim kongresom? Kad će napokon biti? Je li već ustaljen datum. Sve bih ja to morala ranije znati, da uredim svoje školske poslove prema tome. Javite mi, molim Vas, točno. Čujem, da već imam kvartir u Poznanju kod dobrih i dragih ljudi. Pismo gosp. Szobera s Vašim potpisom primila sam i razveselila se, da ste me se svi zajedno sjetili. Da sam bar i ja bila sa svima Vama! Bude li veliki snijeg a Vi prođete Łazienkama ${ }^{26}$ - sjetite me se. Ovdje kod nas blato i kiša, blato i kiša. Očajno vrijeme. - Mnogo Vas i srdačno pozdravlja Vaša

Zdenka

P. S. Vidite li gdje Jelku Nowińsku ${ }^{27}$ pozdravite je srdačno!

(M-B; PISMO s kuvertom, Zagreb, 16. travnja 1931.)

Dragi Julije, Zagreb, 16. IV. 931.

Danas sam dobila rješenje za dopust i sad mogu da ozbiljno mislim na put u Poljsku. Moj direktor baš nije oduševljen, štoviše, da može, spriječio bi, vidim po svemu, ali ja se uza sve to ipak silno veselim. Jedno mi samo nije jasno. U prospektu „Putnika” stoji da je zajednički odlazak za sve putnike iz Jugoslavije iz Pešte i to dopodne 25/IV, i onda se drnda cijeli dan i cijelu noć do Poznanja. Međutim prospekt Lige veli, da mi iz Zagreba polazimo iz Beča 25/IV poslije podne u 450 (čini mi se), što je svakako bolje i mnogo zgodnije. Vi ste bili u Beogradu, pa ćete znati, što je na stvari. Valjda nije promijenjen plan da se putuje preko Beča! Znate, kad bi se radilo o tom da i mi iz Zgba idemo preko Pešte, razmišljala bih se, bih li pošla. Ono je ubitačan put!

Odavle se malo njih sprema u Poljsku. Osim delegata sv. Jeronima ne znam nikoga osim doktorice Prašek ${ }^{28}$ i mene, koji bi išao. Iz Ljubljane, čujem, da se sprema 12-15 duša!

${ }^{26}$ Kraljevski park s palačom u Varšavi, op. prir.

${ }^{27}$ Profesorica I. ženske realne gimnazije u Zagrebu; supruga prof. Jana Nowinskog, op. prir.

${ }^{28}$ Bronisława Prašek, liječnica i supruga Čeha, liječnika bakteriologa Emila Prašeka, op. prir. 
Sad mora da Vam je u Iloku lijepo! I tu pomalo, ali zbilja pomalo i nekako oprezno ulazi proljeće. Ali zato ćemo se voziti kroz samu svježu zelen. Kada dolazite Vi u Zagreb, a kada putujete u Beč? Noću? Ja ću 24/ IV dopodne i noćiću u Beču.

Mnogo Vas i srdačno pozdravlja

Vaša

Zdenka

(M-B; PISMO s kuvertom, Zagreb, 6. svibnja 1931.)

Dragi Julije,

Sretno sam stigla kući, puna lijepih osjećaja i doživljaja, ali umorna i preumorna od puta i štrapaca. Zlo je, da sam odmah sutradan morala rano ujutro već na posao. Sad istom [vidim], da sam došla kući praznoruka: bez bilježaka, bez novinskih izvještaja, bez ičega. Najgore je, da nisam ponijela, naime nisam dobila, one zaključke našega Sporazuma ${ }^{29}$; htjela bih da o tome izvijestim nešto, a nemam materijala. Zato Vas lijepo molim, da mi, što prije možete, pošaljete sve one zaključke i program rada, riječju sve, što se odnosi na Sporazum. - Inače proživljujem one dosta neugodne časove duševnoga Katzenjammera ${ }^{30}$. Jedino lijepo i utješno ovdje, to je zeleno proljeće, puno, puno cvijeća i mirisa. Onaj put od Celja do Zagreba to je bio zaista put [...] triumph proljeća.

Kako Vam je bez nas?

Ne zaboravite me sasvim.

Mnogo Vas pozdravlja

Vaša

Zdenka.

${ }^{29}$ Sporazum je, u okviru Kongresa prijateljstva (Poljska, 25. travnja - 3. svibnja 1931.), sklopljen 30. travnja 1931. u Varšavi, a jugoslavensku stranu službeno su zastupali Julije Benešić, Zdenka Marković, Veljko Petrović i drugi. Odluke Sporazuma obuhvaćale su razmjenu slavista i književnika, poticanje izdavačke djelatnosti, dodjeljivanje književnih nagrada, održavanje godišnjih kongresa. (Paździerski 2004: 33).

${ }^{30} \mathrm{Njem}$. mamurluk, op. prir. 
(M-B; PISMO s kuvertom, Zagreb, 26. svibnja 1931.)

Dragi Julije,

Duhovi, 931.

(...)

Kako Vi, dragi i zasłużony redaktore? Otkad sam se vratila, češće Vas se sjećam i pri tom mi je uvijek jedno pitanje na pameti, koje sigurno nemam prava da Vam stavljam: što je Vas u životu tako zgazilo, da se Vi do danas niste od toga oporavili? Pa svaki od nas nosi svoje poraze i tragedije, ali ipak dolazi čas, kad se nova snaga u njemu javi, pa on pobaca sve te lješine i mrtvace iz svoga srca i duše, pa počinje da živi novim, velikim, možda većim i ljepšim životom od onoga prije. Ali kod Vas nije tako. Vi još uvijek živite na nekim starim grobljima. Nije li tako? A Vi biste sa svojim sposobnostima i svojim bogatstvom unutarnjim mogli toliko toga, samo da hoćete!

Mnogo Vas i srdačno pozdravlja Vaša

Zdenka.

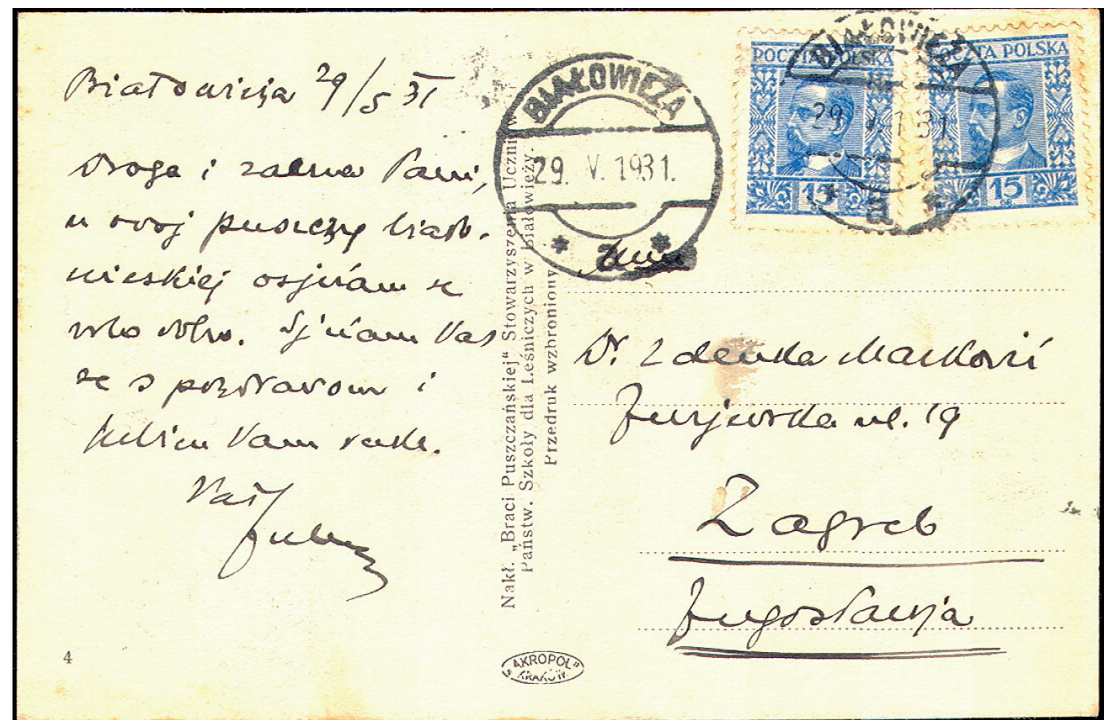


(M-B; PISMO s kuvertom, Zagreb, 23. travnja 1932.)

Dragi gospodine Julije,

Subota, 23 aprila 932.

Eto i mene uoči Vašeg jubileja k Vama da Vam bez mnogo riječi uz prijateljski topao stisak ruke kažem, kako se veselim ovom Vašem danu i Vašoj slavi, što je slavite daleko, na našem poljskom sjeveru. Veselim se, jer je ova slava dokaz, kako Vas Poljaci vole i kako cijene Vaš dugogodišnji pošteni rad. I ja ću danas biti s Vama i s njima, razumije se kao - Poljakinja, ,zacna” i „kochana”. -

Davno, davno mi se već niste javili, čini mi se da mi ljetos, otkako ste otišli, uopće niste pisali. Zaboravljena sam sasvim. - Mi ovdje životarimo, kojekako.

(Ala) su se vremena promijenila! Nevjerojatno je, da je čovjek upravo prije godinu dana mogao onako bezbrižno i mirno i raspoloženo (da) krene na kongres u Poljsku kao ja i svi mi. Baš nam je bilo lijepo. Upravo se navršuje godina dana. (...)

Raduje se s Vama i mnogo Vas i srdačno pozdravlja Vaša

Zdenka M.

(M-B; PISMO s kuvertom, Zagreb, 9. kolovoza 1952.)

Zagreb, 9/VIII. 952.

Dragi, dragi Julije,

Od srca Vam hvala na Vašim dobrim riječima. Trebala sam ih i čekala. Čudila sam se, da se ništa ne javljate. Zaprepastila sam se razabravši iz pisma, da ste u bolnici. Što Vam je? Napišite mi štogod više u Kranjsku goru (Poste restante). Sva sam skršena, iscrpljena duševno i tjelesno, pa ću malo u gore. Znate, da ih volim. A već dva ljeta nisam bila nigdje na odmoru. Sve dobro! 